\title{
ANALYSIS OF THE CLIMATIC FEATURES OF THE REGIONS OF THE PRIMARY APPLICATION OF THE SYSTEMS FOR PRODUCING WATER FROM THE ATMOSPHERIC AIR
}

\author{
Eugeniy Osadchuk ${ }^{1}$, Oleksandr Titlov ${ }^{2}$ \\ ${ }^{1} 1$ Department of mathematics, head teacher, Odessa National Academy of Food Technologies, Odessa, Ukraine \\ osadchuk_e@mail.ru \\ ORCID: http://orcid.org/0000-0002-8955-2041 \\ ${ }^{2}$ Department of Heat-and-Power Engineering and Oil-and-Gas Transportation and Storing, Odessa National Academy of Food Technolo- \\ gies, Odessa, Ukraine \\ titlov1959@gmail.com \\ ORCID: http://orcid.org/0000-0003-1908-5713
}

A R T ICLE INF O
Article history:
Received date 14.07 .2020
Accepted date 12.08 .2020
Published date 31.08 .2020
Section:
Energy
D O I

$10.21303 / 2313-8416.2020 .001390$

KEYWORDS

shortage of water resources systems for obtaining water from air refrigeration machines

\section{ABSTRACT}

The object of research is the thermal and humidity processes occurring during artificial cooling of atmospheric air to the dew point temperature in the evaporators of refrigeration machines of the compression and absorption type.

This study solves the problem of finding energy efficient heat and humidity modes for cooling atmospheric air to the dew point temperature in regions with a shortage of water resources and high solar installations.

It is shown that practically in all considered climatic zones with a shortage of water resources, the process of obtaining water from atmospheric air is most energetically expended in the winter period of the year, and the most energetically efficient - in the summer period. In the summer period of the year, the specific energy consumption is numerically comparable in the cooling temperature range from $5{ }^{\circ} \mathrm{C}$ to $15^{\circ} \mathrm{C}$. It is also shown that the application of the technology of night radiation will create a reserve of natural cold for additional cooling of condensers of refrigerating machines of various types during the entire period of operation.

The area of practical use of the research results: compression and absorption refrigeration machines operating in systems for obtaining water from atmospheric air and taking into account seasonal changes in the thermal and humidity parameters of atmospheric air.

An innovative technological product: energy-efficient systems for obtaining water from atmospheric air based on refrigeration machines of the compression and absorption type, which also work with the help of solar radiation.

Scope of application of the innovative technological product: systems for supplying the population with drinking and process water, mainly in areas with a shortage of water resources.

(C) The Author(s) 2020. This is an open access article under the CC BY license http://creativecommons.org/licenses/by/4.0).

\section{Introduction}

The most valuable resource on the planet in the near future will be water, and the struggle for water resources in the world is one of the factors in modern armed conflicts [1].

To help tackle this problem, in December 2003, the United Nations General Assembly declared 2005-2015 the International Decade for Action "Water for Life".

According to the UN [2]:

a) there are over 1 billion people without sustainable access to clean water. 2.4 billion people more than one third of the world's population - lack access to adequate sanitation;

b) annually more than 2 million people, mainly in developing countries, die from diseases associated with poor water quality and unsatisfactory sanitary and hygienic conditions;

c) currently, more than 40 percent of the world's population lives in areas experiencing moderate or severe water shortages;

d) an increasing number of regions of the world, especially in North Africa and Western and South Asia, are facing the problem of water scarcity, and in regions such as the United States of 
America, China and India, the rate of groundwater consumption exceeds the rate of their recharge, and there is a constant decrease in the level of groundwater.

At the same time, about 70 percent of the earth's surface is covered with water, but 97.5 percent of it consists of salt water. The remaining 2.5 percent is fresh water, nearly two-thirds of which is frozen in ice caps. Meanwhile, most of the fresh water is in the 1 kilometer layer of the atmosphere.

According to work [3], the average absolute humidity near the earth's surface is $11 \mathrm{~g} / \mathrm{m}^{3}$, and in tropical regions it reaches $25 \mathrm{~g} / \mathrm{m}^{3}$ and above. A large number of countries in the tropical zone suffer from the lack of fresh water, although its content in the atmosphere is very significant.

Therefore, one of the most important tasks is the development of technologies allowing to extract water from the air, and directly at the place where it is needed.

Since ancient times, fresh water, in very limited quantities, has been obtained by collecting condensed droplets from the air as a result of natural daily radiation cooling of the earth's surface (cooling at night of porous stones with the formation of dew). When the temperature drops by $10-15{ }^{\circ} \mathrm{C}, 10-14 \mathrm{~g}$ of water can be extracted from each cubic meter.

To increase the efficiency of the condensation of water vapor under these conditions, intensifying elements are used - cold accumulators (crushed stone), heat pipes that provide heat transfer over long distances and a system of sorbents operating in a cyclic charge-discharge mode [4].

The use of natural night cooling does not imply energy consumption during the operation of systems for obtaining water from atmospheric air (SOW), however, in real economic activity, methods based on artificial cooling have the greatest prospects [5]. Refrigerating machines of various types (compression, absorption) are guaranteed to provide cooling of atmospheric air below the dew point temperature and high performance of the SOW throughout the day $[6,7]$.

The main disadvantage of SOW based on refrigerating machines, including heat-using absorption type [5-7], is associated with the need to use electrical energy to a greater (for compression systems) or less (for absorption systems on solar energy) degree.

In this regard, the search for energy-efficient operating modes of refrigeration machines as SOW part becomes relevant.

\section{1. The object of research}

The object of research is the thermal and humidity processes occurring during artificial cooling of atmospheric air to the dew point temperature in the evaporators of refrigeration machines of the compression and absorption type.

\section{2. Problem description}

The energy efficiency of refrigeration machines of both compression and absorption types is influenced in the same way by the temperatures of the refrigerated object and the environment, respectively $[8,9]$.

With an increase in the ambient temperature and, accordingly, with an increase in the condensation temperature of the refrigerant, the energy efficiency of refrigeration machines decreases.

Conversely, with an increase in the temperature of the object of cooling and, accordingly, with an increase in the boiling point of the refrigerant, the energy efficiency of refrigeration machines increases.

To reduce the condensation temperature of the refrigerant, interesting solutions have been proposed, associated with the use of night radiation for the reserve of natural cold [10, 11]. In this case, the effect of reducing the temperature to $5^{\circ} \mathrm{C}$ was achieved both in a region with a continental climate [10] and in a tropical climate [11].

\section{3. Proposed solution to the problem}

Obviously, in order to increase the SOW condensate-water productivity, the boiling point of the refrigerant should be as low as possible, but not lower than $0{ }^{\circ} \mathrm{C}$ to prevent frost freezing on the evaporator. 
At the same time, in modern literary sources there are no specific recommendations for the final temperatures of cooling of atmospheric air in the evaporators of refrigerating machines.

The purpose of the study is to develop recommendations for SOW developers on the final temperatures of cooling of atmospheric air in evaporators of refrigerating machines based on thermodynamic analysis of heat and moisture processes.

\section{Materials and methods of research}

For the analysis of climatic features, typical regions of the planet with problematic water resources and with a simultaneous high solar insolation were selected. These are the cities of North Africa and the Middle East: Algeria (Algeria); Damascus (Syria); Cairo (Egypt); Tel Aviv (Israel).

The presence of intense solar radiation makes it possible to include heat-using absorption ammonia-water refrigerating machines in the SOW schemes and minimize the consumption of electrical energy for artificial cooling [12].

Statistical data on weather conditions in these areas were taken from open Internet resources [13]. For each season (summer, autumn, winter, spring), the average, maximum and minimum temperatures and the corresponding relative humidity $(\varphi)$ are determined.

The moisture content of atmospheric air is calculated through the partial pressure of saturated water vapor

$$
d=616 \frac{p}{10^{5}-p} .
$$

To determine the partial pressure of water vapor, the tabular data [14] are approximated and the following relation is obtained

$$
p=a+b t+c t^{2}+d t^{3}+e t^{4}+f t^{5}, \mathrm{~Pa},
$$

where $a=611,366 ; b=44,427 ; c=1,423 ; d=0,027 ; e=0,0003 ; f=2,765 \cdot 10^{-6} ; t$ - temperature, ${ }^{\circ} \mathrm{C}$.

The specific enthalpy of atmospheric air is determined

$$
i=1,006 \cdot t+(2502,7+1,844 \cdot t) \cdot \frac{d}{1000} \mathrm{~kJ} / \mathrm{kg}
$$

The calculation of the thermal and humidity process of polytropic cooling of atmospheric air is carried out for three cases of the final saturation temperatures of $5{ }^{\circ} \mathrm{C}, 10^{\circ} \mathrm{C}, 15^{\circ} \mathrm{C}$.

To determine the energy efficiency of the thermal and humidity processes of cooling and dehumidification, a complex $\Delta i / \Delta d$ is used, which is a slope (process beam, heat-humidity ratio).

For our task of obtaining water from atmospheric air, this complex characterizes the energy efficiency of the process, i. e. the amount of heat that must be removed from the flow of atmospheric air to get $1 \mathrm{~kg}$ of condensate water.

It is obvious that the numerically smaller this complex, the more energetically efficient is the heat and humidity process for obtaining water from atmospheric air.

Table 1 shows the parameters of atmospheric air (specific enthalpy $i_{t_{0}}$ and moisture content $\left.d_{t_{0}}\right)$ at full saturation $(\varphi=100 \%)$ and final temperature $t_{\mathrm{o}}$. The calculation results for four cities of the world are shown in Table 2.

Table 1

Atmospheric air parameters at final temperature

\begin{tabular}{ccc}
\hline $\boldsymbol{t}_{\mathbf{0}},{ }^{\circ} \mathbf{C}$ & $\boldsymbol{i}_{\boldsymbol{t}_{\mathbf{0}}}, \mathbf{k J} / \mathbf{k g}$ & $\boldsymbol{d}_{\boldsymbol{t}_{\mathbf{0}}, \mathbf{g} / \mathbf{k g}}$ \\
\hline 5 & 18.79 & 5.74 \\
10 & 29.58 & 7.73 \\
15 & 42.44 & 10.8
\end{tabular}


Table 2

Thermal and humidity parameters of atmospheric air in some cities of the world

\begin{tabular}{|c|c|c|c|c|c|c|}
\hline \multicolumn{7}{|c|}{ Tel Aviv } \\
\hline & \multicolumn{3}{|c|}{ Winter } & \multicolumn{3}{|c|}{ Spring } \\
\hline & av & $\max$ & $\min$ & av & $\max$ & $\min$ \\
\hline 1 & 2 & 3 & 4 & 5 & 6 & 7 \\
\hline$t,{ }^{\circ} \mathrm{C}$ & 15.9 & 27.4 & 7 & 22.8 & 40.7 & 10.4 \\
\hline$\phi, \%$ & 60.5 & 96 & 16 & 56.1 & 96 & 9 \\
\hline$d, \mathrm{~g} / \mathrm{kg}$ & 6.9 & 22.4 & 0.9 & 9.7 & 48.9 & 0.7 \\
\hline$i, \mathrm{~kJ} / \mathrm{kg}$ & 33.4 & 84.7 & 9.5 & 47.7 & 167.0 & 12.2 \\
\hline$\Delta i / \Delta d\left(t=5^{\circ} \mathrm{C}\right)$ & 13.2 & 4.0 & - & 7.2 & 3.4 & - \\
\hline$\Delta i / \Delta d\left(t=10^{\circ} \mathrm{C}\right)$ & - & 3.8 & - & 9.1 & 3.3 & - \\
\hline \multirow[t]{3}{*}{$\Delta i / \Delta d\left(t=15^{\circ} \mathrm{C}\right)$} & - & 3.6 & - & & 3.3 & - \\
\hline & \multicolumn{3}{|c|}{ Summer } & \multicolumn{3}{|c|}{ Autumn } \\
\hline & av & $\max$ & $\min$ & av & $\max$ & $\min$ \\
\hline$t,{ }^{\circ} \mathrm{C}$ & 28.3 & 40.7 & 20.2 & 25.9 & 34.3 & 14.9 \\
\hline$\phi, \%$ & 61.6 & 90 & 10 & 54.4 & 90 & 10 \\
\hline$d, \mathrm{~g} / \mathrm{kg}$ & 14.9 & 45.6 & 1.46 & 11.5 & 31.5 & 1.1 \\
\hline$i, \mathrm{~kJ} / \mathrm{kg}$ & 66.5 & 158.5 & 24.03 & 55.4 & 115.5 & 17.6 \\
\hline$\Delta i / \Delta d\left(t=5^{\circ} \mathrm{C}\right)$ & 5.2 & 3.5 & - & 6.4 & 3.7 & - \\
\hline$\Delta i / \Delta d\left(t=10^{\circ} \mathrm{C}\right)$ & 5.1 & 3.4 & - & 6.9 & 3.6 & - \\
\hline$\Delta i / \Delta d\left(t=15^{\circ} \mathrm{C}\right)$ & 5.9 & 3.3 & - & 19.4 & 3.5 & - \\
\hline \multicolumn{7}{|c|}{ Cairo } \\
\hline & \multicolumn{3}{|c|}{ Winter } & \multicolumn{3}{|c|}{ Spring } \\
\hline & av & $\max$ & $\min$ & av & $\max$ & $\min$ \\
\hline$t,{ }^{\circ} \mathrm{C}$ & 22.8 & 30.8 & 16.8 & 26.7 & 44.2 & 10.8 \\
\hline$\phi, \%$ & 52.9 & 88 & 17 & 41.4 & 96 & 6 \\
\hline$d, \mathrm{~g} / \mathrm{kg}$ & 9.2 & 25.1 & 2.1 & 9.1 & 59.7 & 0.5 \\
\hline$i, \mathrm{~kJ} / \mathrm{kg}$ & 46.4 & 95.2 & 21.9 & 50.1 & 198.7 & 12.1 \\
\hline$\Delta i / \Delta d\left(t=5^{\circ} \mathrm{C}\right)$ & 8.0 & 4.0 & - & 9.3 & 3.3 & - \\
\hline$\Delta i / \Delta d\left(t=10^{\circ} \mathrm{C}\right)$ & 11.4 & 3.8 & - & 15.1 & 3.3 & - \\
\hline$\Delta i / \Delta d\left(t=15^{\circ} \mathrm{C}\right)$ & - & 3.7 & - & - & 3.2 & - \\
\hline
\end{tabular}

\begin{tabular}{ccccccc}
\hline & \multicolumn{3}{c}{ Summer } & \multicolumn{3}{c}{ Autumn } \\
\cline { 2 - 7 } & av & max & min & av & max & min \\
\hline$t,{ }^{\circ} \mathrm{C}$ & 30.9 & 41.2 & 22 & 25.9 & 38 & 15.7 \\
$\phi, \%$ & 50.1 & 94 & 12 & 53.9 & 90 & 17 \\
$d, \mathrm{~g} / \mathrm{kg}$ & 14.2 & 49.2 & 1.9 & 11.3 & 39.1 & 1.9 \\
$i, \mathrm{~kJ} / \mathrm{kg}$ & 67.4 & 168.3 & 27.1 & 54.9 & 138.8 & 20.5 \\
$\Delta i / \Delta d\left(t=5^{\circ} \mathrm{C}\right)$ & 5.8 & 3.4 & - & 6.5 & 3.6 & - \\
$\Delta i / \Delta d\left(t=10^{\circ} \mathrm{C}\right)$ & 5.9 & 3.3 & - & 7.1 & 3.5 & - \\
$\Delta i / \Delta d\left(t=15^{\circ} \mathrm{C}\right)$ & 7.4 & 3.3 & - & 23.5 & 3.4 & - \\
\hline
\end{tabular}




\begin{tabular}{|c|c|c|c|c|c|c|}
\hline 1 & 2 & 3 & 4 & 5 & 6 & 7 \\
\hline \multicolumn{7}{|c|}{ Damascus } \\
\hline & \multicolumn{3}{|c|}{ Winter } & \multicolumn{3}{|c|}{ Spring } \\
\hline & av & $\max$ & $\min$ & av & $\max$ & $\min$ \\
\hline$t,{ }^{\circ} \mathrm{C}$ & 11.8 & 24.4 & -1.0 & 22.8 & 37.8 & 7.8 \\
\hline$\phi, \%$ & 68.9 & 100.0 & 13.0 & 36.9 & 95.0 & 9.0 \\
\hline$d, \mathrm{~g} / \mathrm{kg}$ & 5.9 & 19.4 & 0.5 & 6.4 & 40.9 & 0.6 \\
\hline$i, \mathrm{~kJ} / \mathrm{kg}$ & 26.9 & 74.0 & 0.1 & 39.2 & 143.3 & 9.3 \\
\hline$\Delta i / \Delta d\left(t=5^{\circ} \mathrm{C}\right)$ & 39.6 & 4.0 & - & 31.7 & 3.5 & - \\
\hline$\Delta i / \Delta d\left(t=10^{\circ} \mathrm{C}\right)$ & - & 3.8 & - & - & 3.4 & - \\
\hline \multirow[t]{3}{*}{$\Delta i / \Delta d\left(t=15^{\circ} \mathrm{C}\right)$} & - & 3.7 & - & - & 3.3 & - \\
\hline & \multicolumn{3}{|c|}{ Summer } & \multicolumn{3}{|c|}{ Autumn } \\
\hline & av & $\max$ & $\min$ & av & $\max$ & $\min$ \\
\hline$t,{ }^{\circ} \mathrm{C}$ & 29.0 & 39.8 & 14.6 & 23.4 & 40.0 & 8.8 \\
\hline$\phi, \%$ & 43.0 & 97.0 & 10.0 & 49.3 & 100.0 & 10.0 \\
\hline$d, \mathrm{~g} / \mathrm{kg}$ & 10.8 & 47.0 & 1.0 & 8.9 & 49.1 & 0.7 \\
\hline$i, \mathrm{~kJ} / \mathrm{kg}$ & 56.9 & 161.0 & 17.3 & 46.1 & 166.7 & 10.6 \\
\hline$\Delta i / \Delta d\left(t=5^{\circ} \mathrm{C}\right)$ & 7.5 & 3.5 & - & 8.8 & 3.4 & - \\
\hline$\Delta i / \Delta d\left(t=10^{\circ} \mathrm{C}\right)$ & 8.8 & 3.4 & - & 14.7 & 3.3 & - \\
\hline$\Delta i / \Delta d\left(t=15^{\circ} \mathrm{C}\right)$ & 507.5 & 3.3 & - & - & 3.2 & - \\
\hline \multicolumn{7}{|c|}{ Algeria } \\
\hline & \multicolumn{3}{|c|}{ Winter } & \multicolumn{3}{|c|}{ Spring } \\
\hline & av & $\max$ & $\min$ & av & $\max$ & $\min$ \\
\hline$t,{ }^{\circ} \mathrm{C}$ & 14.9 & 23.6 & 6.9 & 17.7 & 28.5 & 9.1 \\
\hline$\phi, \%$ & 69.2 & 91.0 & 26.0 & 70.9 & 95.0 & 23.0 \\
\hline$d, \mathrm{~g} / \mathrm{kg}$ & 7.3 & 16.8 & 1.6 & 9.0 & 23.7 & 1.6 \\
\hline$i, \mathrm{~kJ} / \mathrm{kg}$ & 33.6 & 66.5 & 11.0 & 40.5 & 89.1 & 13.3 \\
\hline$\Delta i / \Delta d\left(t=5^{\circ} \mathrm{C}\right)$ & 9.3 & 4.3 & - & 6.7 & 3.9 & - \\
\hline$\Delta i / \Delta d\left(t=10^{\circ} \mathrm{C}\right)$ & - & 4.1 & - & 8.9 & 3.7 & - \\
\hline \multirow[t]{3}{*}{$\Delta i / \Delta d\left(t=15^{\circ} \mathrm{C}\right)$} & - & 4.0 & - & - & 3.6 & - \\
\hline & \multicolumn{3}{|c|}{ Summer } & \multicolumn{3}{|c|}{ Autumn } \\
\hline & av & $\max$ & $\min$ & av & $\max$ & $\min$ \\
\hline$t,{ }^{\circ} \mathrm{C}$ & 25.5 & 31.3 & 18.6 & 21.9 & 30.1 & 10.6 \\
\hline$\phi, \%$ & 74.8 & 96.0 & 34 & 70.9 & 98 & 34 \\
\hline$d, \mathrm{~g} / \mathrm{kg}$ & 15.4 & 28.3 & 4.5 & 11.7 & 26.9 & 2.7 \\
\hline$i, \mathrm{~kJ} / \mathrm{kg}$ & 65.1 & 103.9 & 30.2 & 51.7 & 99.1 & 17.5 \\
\hline$\Delta i / \Delta d\left(t=5^{\circ} \mathrm{C}\right)$ & 4.8 & 3.8 & - & 5.5 & 3.8 & - \\
\hline$\Delta i / \Delta d\left(t=10^{\circ} \mathrm{C}\right)$ & 4.6 & 3.6 & - & 5.6 & 3.6 & - \\
\hline$\Delta i / \Delta d\left(t=15^{\circ} \mathrm{C}\right)$ & 4.9 & 3.5 & - & 10.6 & 3.5 & - \\
\hline
\end{tabular}

Note: Complex $\frac{\Delta i}{\Delta d}=\frac{i_{t_{i}}-i_{t_{0}}}{d_{t_{i}}-d_{t_{0}}}$, where $i_{t_{i}}, i_{t_{0}}$ are the specific enthalpies of atmospheric air at the current temperature and the

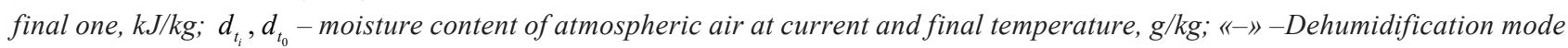
is not implemented 


\section{Research results}

For more informational content of the process of analyzing the calculation results, the dependences of the thermal and humidity parameters for various cities were built (Fig. 1).
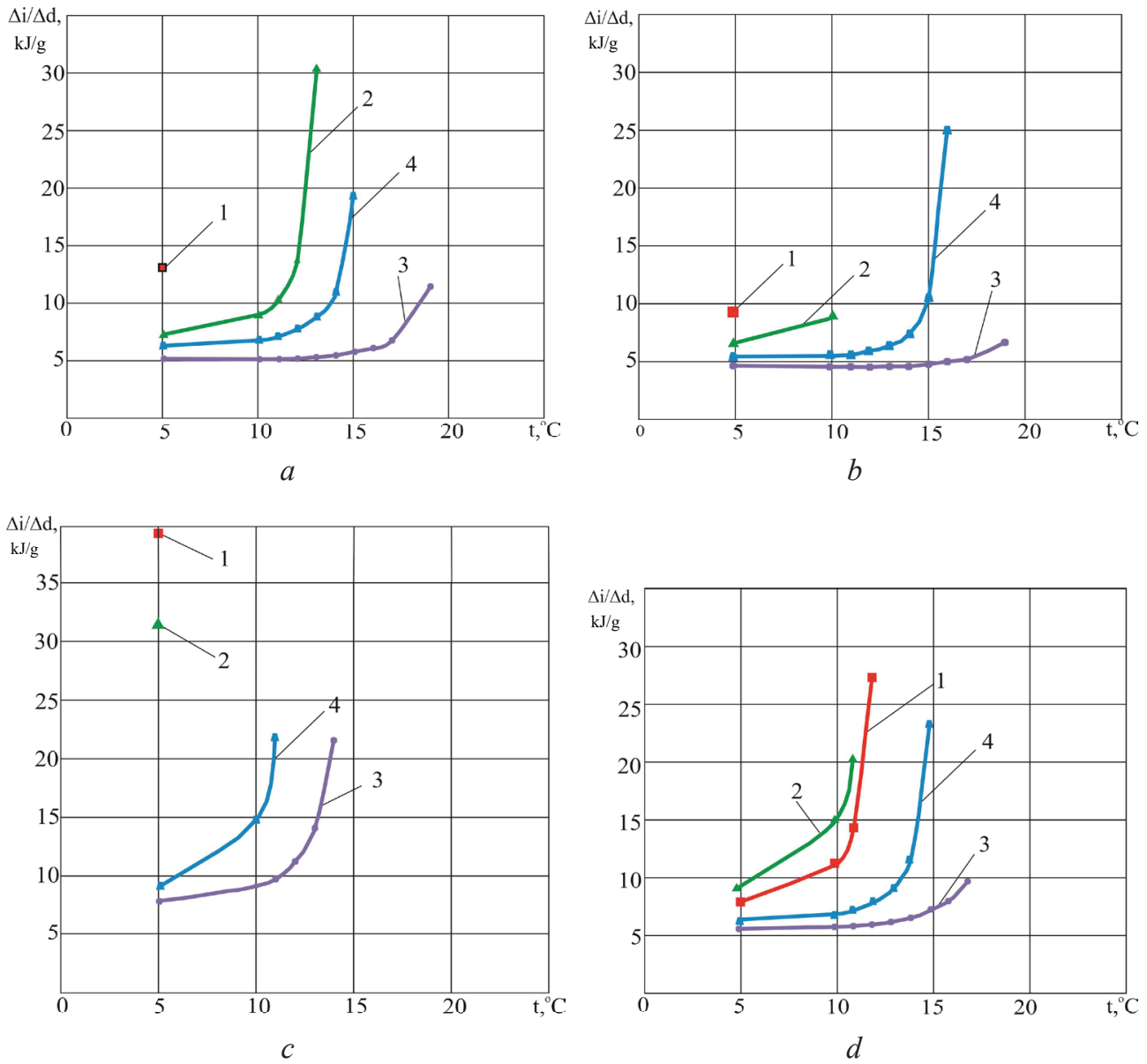

Fig. 1. Dependences of thermal and humidity parameters during cooling of atmospheric air on the minimum cooling temperature for different cities of the world: $a$-Tel Aviv; $b$-Algeria; $c$-Damascus; $d$-Cairo; 1 - winter; 2 - spring; 3 - summer; 4 - autumn

\section{Discussion of research results}

To determine the tendencies of change in the course of the calculated dependences in Fig. 1, $\boldsymbol{a}, \boldsymbol{b}, \boldsymbol{d}$, the final temperatures of air cooling in the evaporators of refrigerating machines were extended upwards.

As a result, the obtained calculated dependencies showed that the SOW operation in winter and spring in most cases requires maximum cooling of atmospheric air (up to $5-10{ }^{\circ} \mathrm{C}$ ), and the processes themselves are most energy-consuming.

Calculations have shown that the most energetically efficient operating modes of the SPV take place in the summer period. At the same time, for Tel Aviv, Algeria and Cairo, it is enough to cool the atmospheric air to $17-18{ }^{\circ} \mathrm{C}$ and do without additional costs for deeper cooling.

It should be noted that this study is intended to draw the attention of specialists in the field of refrigeration technology to the peculiarities of the climate in which the development is supposed to be exploited. And at the same time, take into account the seasonal change in the thermal and humidity parameters of the atmospheric air.

This applies to the greatest extent to SOW, which work with atmospheric air, which undergoes not only seasonal, but also daily changes in thermal and humidity parameters.

For example, taking into account seasonal changes in the thermal and humidity parameters of atmospheric air during a calendar year when controlling a compression refrigerator made it possible to reduce energy consumption during operation by up to $40 \%$ [15]. 
For absorption refrigeration device, taking into account climatic changes in operating conditions made it possible to increase energy efficiency up to $35 \%$ [16].

\section{Conclusions}

1. Application of technology of night radiation in SOW will allow creating a reserve of natural cold for additional cooling of condensers of refrigerating machines of various types during the entire period of operation [17].

2. Practically in all considered climatic zones with water scarcity, the process of obtaining water from atmospheric air is most energetically expended in the winter period of the year, and the most energetically efficient - in the summer period.

3. In the summer period of the year, specific energy consumption is numerically comparable when the final temperature changes during the cooling process from $5{ }^{\circ} \mathrm{C}$ to $15^{\circ} \mathrm{C}$, which will allow organizing an energy-saving process of operation of compression and absorption refrigerators by reducing the boiling point in the evaporator.

\section{References}

[1] A new global partnership: eradicate poverty and transform economies through sustainable development (2013). The Report of the High-Level Panel of Eminent Persons on the Post-2015 Development Agenda. Available at: https://sustainabledevelopment. un.org/index.php?page $=$ view \&type $=400 \& n r=893 \&$ menu $=1561$

[2] International Decade for Action "Water for Life", 2005-2015. UN. Available at: https:/www.un.org/ru/waterforlifedecade/

[3] Alekseev, V. V., Chekarev, K. V. (1996). Poluchenie presnoi vody iz vlazhnogo vozdukha. Aridnye ekosistemy, 2, 2-3.

[4] Perelshtein, B. Kh. (2008). Novye energeticheskie sistemy. Kazan: Izd-vo Kazan. gos. tekhn. un-ta, 244.

[5] Osadchuk, E. A., Titlov, A. S., Kuzakon, V. M., Shlapak, G. V. (2015). Development of schemes of pump and gasoline-pump absorption water-ammonia refrigeration machines to work in a system of water production from the air. Technology Audit and Production Reserves, 3 (3 (23)), 30-37. doi: http://doi.org/10.15587/2312-8372.2015.44139

[6] Kholodkov, A., Osadchuk, E., Titlov, A., Boshkova, I., Zhihareva, N. (2018). Improving the energy efficiency of solar systems for obtaining water from atmospheric air. Eastern-European Journal of Enterprise Technologies, 3 (8 (93)), 41-51. doi: http:// doi.org/10.15587/1729-4061.2018.133643

[7] Titlov, A., Osadchuk, E., Tsoy, A., Alimkeshova, A., Jamasheva, R. (2019). Development of cooling systems on the basis of absorption water-ammonia refrigerating machines of low refrigeration capacity. Eastern-European Journal of Enterprise Technologies, 2 (8 (98)), 57-67. doi: http://doi.org/10.15587/1729-4061.2019.164301

[8] Moroziuk, T. V. (2006). Teoriia kholodilnykh mashin i teplovykh nasosov. Odessa: Studiia «Negociant», 712.

[9] Galimova, L. I. (1997). Absorbcionnye kholodilnye mashiny i teplovye nasosy. Astrakhan: Izd-vo Astrakhanskogo tekhnicheskogo universiteta, 226.

[10] Tsoy, A. P., Granovskii, A. S., Tsoy, D. A., Baranenko, A. V. (2014). Vliianie klimata na rabotu kholodilnoi sistemy, ispolzuiuschei effektivnoe izluchenie v kosmicheskoe prostranstvo. Kholodilnaia tekhnika, 12, 38-43.

[11] Prommajak, T., Phonruksa, J., Pramuang, S. (2008). Passive cooling of air at night by the nocturnal radiation in Loei, Thailand. Renewable Energy, 3 (1), 33-40.

[12] Titlov, O. S., Kuzakon, V. M., Osadchuk, Ye. O., Vasyliv, O. B. (2017). Pat. No. 114658 UA. Sposib oderzhannia vody z atmosfernoho povitria ta ustanovka dlia yoho zdiisnennia. MPK: E03B 3/28, F25B 15/10, F25D 21/14 (2006.01). No. a 201506905; declareted: 13.07.2015; published: 10.07.2017, Bul. No. 13.

[13] Weather in 243 countries of the world. Weather schedule. Available at: https://rp5.ru

[14] Bogdanov, S. N. et. al. (1999). Spravochnik. Svoistva veschestv. Kholodilnaia tekhnika. Saint Petersburg: SPbGAKHPT, 320.

[15] Vagin, A. V., Zverkov, V. P., Russo, V. E., Shatrov, Iu. M. (1999). Novaia sistema termoregulirovaniia bytovoi kholodilnoi tekhniki klassa KHOLT. Kholodilnaia tekhnika, 9, 28-30.

[16] Selivanov, A. P. (2013). Absorbtsionnye kholodilnye apparaty sezonnogo tipa. Sovremennoe sostoianie i tendentsii razvitiia. Zbirnik naukovikh prats Natsionalnogo universitetu korablebuduvannia, 5-6, 82-88.

[17] Titlov, A., Tsoy, A., Alimkeshova, A., Jamasheva, R. (2019). Development of cooling systems using the night-radiation effect. ScienceRise, 12 (65), 24-33. doi: http://doi.org/10.15587/2313-8416.2019.189492 